\title{
Pesticide residues in brassica vegetables in 2010-2012 and risk estimation of consumers' exposure
}

\section{Pozostałości środków ochrony roślin w warzywach kapustnych w latach 2010-2012 i oszacowanie narażenia konsumentów}

\author{
Anna Kurdziel, Ewa Szpyrka, Aneta Matyaszek, Magdalena Podbielska, \\ Julian Rupar, Magdalena Słowik-Borowiec
}

\begin{abstract}
Summary
The paper presents the results on pesticide residues in brassica vegetables carried out in 2010-2012 and risk estimation of consumers' health depending on the exposure (long-term and short-term). 122 samples were analysed on the pesticide residue content. The pesticide residues were detected in $44(36 \%)$ of all analysed samples. The most often detected residues were chlorpyrifos and azoxystrobin. In 2 samples of Chinese cabbage, pyrimethanil residues were found, as an active substance of plant protection product not recommended for protection of this crop. Maximum Residue Limits were exceeded in $6 \%$ of analysed samples. The results of risk estimation of the long-term and short-term exposure to consumers health revealed that the level of detected pesticide residues in the cabbage vegetables after their consumption did not pose a threat to people's health.
\end{abstract}

Key words: pesticide residues, brassica vegetables, dietary exposure

\section{Streszczenie}

W pracy przedstawiono wyniki badań na obecność pozostałości środków ochrony roślin (ś.o.r.) w warzywach z grupy kapustnych, przeprowadzonych w latach 2010-2012, a także wyniki oszacowania krótkoterminowego i długoterminowego narażenia zdrowia konsumentów. Łącznie przebadano 122 próbki. Pozostałości ś.o.r. stwierdzono w 44 próbkach (36\%). Najczęściej wykrywanymi substancjami czynnymi były: chloropiryfos i azoksystrobina. W 2 próbkach kapusty pekińskiej wykryto pirymetanil - substancję czynną ś.o.r., niezalecanych $w$ tej uprawie. Przekroczenia najwyższych dopuszczalnych poziomów pozostałości stwierdzono w $6 \%$ analizowanych próbek. Oszacowane narażenie długoterminowe i krótkoterminowe konsumentów na obecność pozostałości ś.o.r. w warzywach kapustnych wykazało, że ich spożycie nie stwarza zagrożenia dla zdrowia ludzi.

Słowa kluczowe: pozostałości środków ochrony roślin, pestycydy, warzywa kapustne, narażenie

\footnotetext{
nstytut Ochrony Roślin - Państwowy Instytut Badawczy

Terenowa Stacja Doświadczalna

Langiewicza 28, 35-101 Rzeszów

a.kurdziel@iorpib.poznan.pl
} 


\section{Wstęp / Introduction}

Jedną z najpowszechniejszych metod ochrony roślin i produktów roślinnych przed działaniem szkodliwych organizmów jest stosowanie chemicznej ochrony roślin. Z uwagi na fakt, iż substancje czynne (s.cz.) występujące w tych preparatach bardzo często charakteryzują się dużą trwałością i zdolnością do biokumulacji w środowisku, a także wykazują własności kancerogenne, teratogenne i mutagenne, stanowią one potencjalne zagrożenie dla zdrowia człowieka (Ullmann’s 2007). Produkty roślinne stanowią podstawowy składnik naszej diety, dlatego bardzo ważna staje się ocena poziomów pozostałości środków ochrony roślin (ś.o.r.) w nich występujących oraz ocena ryzyka dla zdrowia konsumenta.

W pracy przedstawione zostały wyniki badań na obecność pozostałości ś.o.r. W warzywach $\mathrm{z}$ grupy kapustnych, przeprowadzonych w latach 2010-2012, a także wyniki oszacowania krótkoterminowego i długoterminowego narażenia zdrowia konsumentów.

\section{Materiały i metody / Materials and methods}

Materiał do badań stanowiły próbki, losowo pobierane przez inspektorów Wojewódzkich Inspektoratów Ochrony Roślin i Nasiennictwa w ramach urzędowej kontroli (głównie $\mathrm{z}$ terenu południowo-wschodniej Polski), jak również próbki wykonywane na zlecenie producentów i przetwórców warzyw. Kontroli poddano 5 upraw, tj. brokułu, kalafiora, kapusty głowiastej białej, kapusty brukselskiej oraz kapusty pekińskiej. Program badań obejmował oznaczenie 130 (w 2010 roku), 145 (w 2011 roku) i 159 (w 2012 roku) substancji czynnych ś.o.r. wraz z ich metabolitami (tab. 1).

Do oznaczania stosowano akredytowaną, według normy PN-EN ISO/IEC 17025 (2005), metodę analityczną, corocznie sprawdzaną poprzez udział w badaniach biegłości organizowanych przez Unię Europejską, umożliwiająca jednoczesne wykrycie wielu związków. Metoda ta polega na homogenizacji próbki $\mathrm{z}$ acetonem, a następnie na przeprowadzeniu pozostałości ś.o.r. (przez podział ciecz-ciecz) do dichlorometanu. Uzyskane ekstrakty odparowuje się do sucha za pomocą wyparki obrotowej w temperaturze poniżej $40^{\circ} \mathrm{C}$, pozostałości rozpuszcza się $\mathrm{w}$ eterze naftowym, a następnie oczyszcza na kolumnie florisilowej (Valverde-Garcia i wsp. 1993; Sadło i Szpyrka 2001).

Ilościowe oznaczanie pozostałości ś.o.r. wykonywane jest techniką chromatografii gazowej z wykorzystaniem detektorów selektywnych: wychwytu elektronów i azotowo-fosforowego (GC-ECD/NPD). Uzyskane wyniki porównuje się z najwyższymi dopuszczalnymi poziomami pozostałości (NDP) (Rozporządzenie 2005).

W przypadku przekroczeń NDP, zgodnie z rozporządzeniem Ministra Zdrowia z dnia 17 października 2007 r., laboratorium potwierdzało tożsamość wykrytej substancji, a jej stężenie weryfikowało poprzez analizę dodatkowej porcji analitycznej, pochodzącej $\mathrm{z}$ oryginalnej próbki laboratoryjnej (Rozporządzenie 2007). Oceniając przekro- czenia NDP, brano pod uwagę niepewność jaką obarczony był wynik.

Zgodnie z Rozporządzeniem 396/2005 Parlamentu Europejskiego przewlekłe (długoterminowe) lub w niektórych przypadkach, ostre (krótkoterminowe) narażenie konsumentów na pozostałości pestycydów pobieranych z żywnością powinno być oszacowane zgodnie z procedurami i praktykami wspólnotowymi, z uwzględnieniem zaleceń opublikowanych przez Światową Organizację Zdrowia (Rozporządzenie 2005).

Przy ocenie ryzyka długoterminowego narażenia człowieka na pozostałości ś.o.r., wartości dziennego pobrania pozostałości porównywano do wartości dopuszczalnego dziennego pobrania (ADI - Acceptable Daily Intake). Wartość ADI określa ilość substancji w żywności lub wodzie pitnej, w przeliczeniu na masę ciała, jaka może być przyjęta przez dobę $\mathrm{w}$ ciągu całego życia, bez znacznego zagrożenia dla zdrowia konsumenta, która została wyznaczona na podstawie wszystkich znanych faktów w czasie oceny (WHO 1997).

Szacowane dzienne spożycie (EDI - Estimated Daily Intake) obliczane było według równania:

$$
\mathrm{EDI}=\sum \frac{\mathrm{RL} * \mathrm{FR}}{\text { b.w. }}
$$

$\mathrm{RL}$ - odpowiedni poziom pozostałości w produkcie $[\mathrm{mg} / \mathrm{kg}]$,

FR - 97,5 percentyl, dzienne spożycie danego produktu [kg/dzień],

b.w. - masa ciała [kg].

W państwach członkowskich, w tym również w Polsce, w przypadku wykrycia przekroczeń NDP w próbkach objętych urzędową kontrolą dokonuje się oceny ryzyka wynikającego $\mathrm{z}$ narażenia krótkoterminowego obliczając tzw. wartość przewidywanego krótkoterminowego pobrania z żywnością na podstawie wyniku badania próbki PSTI (Predicted Short Term Intake from sampling result), którą to następnie porównuje się $\mathrm{z}$ tzw. ostrą dawką referencyjną (ARfD - Acute Reference Dose) lub w przypadku jej braku, z ADI (Struciński i wsp. 2007; Ludwicki i Kostka 2008). ARfD określa ilość substancji w żywności lub wodzie pitnej, w przeliczeniu na masę ciała, jaka może być przyjęta przez krótki okres czasu, zwykle w trakcie jednego posiłku lub jednego dnia, bez znaczącego ryzyka dla zdrowia konsumentów (WHO 1997).

$\mathrm{Z}$ powodu braku pełnych, krajowych danych dotyczących 97,5 percentyla, do obliczeń wykorzystano informacje $\mathrm{z}$ modelu brytyjskiego stosowanego przez Urząd Bezpieczeństwa Pestycydów Ministerstwa ds. Środowiska, Żywności i Rolnictwa (PSD 2006).

Przekroczenia NDP stwierdzono dla brokułu i kapusty pekińskiej. W przypadku tych warzyw mamy do czynienia z sytuacją gdy masa produktu jest większa bądź równa „dużej porcji”, PSTI obliczano ze wzoru (Struciński i wsp. 2007; FAO/WHO 2009):

$$
\text { PSTI }=\frac{\mathrm{LP}^{*} \mathrm{HR}^{*} \mathrm{v}}{\text { b.w. }}
$$


LP - „duża porcja” 97,5 percentyl spożycia danego produktu przez określoną populację [kg/dzień],

HR - poziom pozostałości w części jadalnej próbki produktu zbiorczego [mg/kg],

$\mathrm{v}$ - współczynnik zmienności,

b.w. - masa ciała [kg].

Ocena ryzyka narażenia zdrowia związanego ze spożyciem warzyw kapustnych zawierających pozostałości ś.o.r. dokonana została dla dwóch grup konsumentów: osób dorosłych, tzw. populacji generalnej [masa ciała (m.c.) - $76 \mathrm{~kg}$ ] i dzieci w wieku 1,5 - 4 lat (m.c. $-14,5 \mathrm{~kg}$ ).

\section{Wyniki i dyskusja / Results and discussion}

Wykonano analizy 122 próbek warzyw $\mathrm{z}$ grupy kapustnych. Pozostałości ś.o.r. stwierdzono w 44 próbkach (36\%), przy czym w 7 próbkach $(6 \%)$ przekroczyły one poziom NDP. Przekroczenia te wystąiły w 1 próbce brokułu (pozostałość chloropiryfosu) i W 5 próbkach kapusty pekińskiej (pozostałości chlorotalonilu, chloropiryfosu, dimetoatu i trifloksystrobiny). Zgodnie z polskimi przepisami, informacje o przekroczeniach NDP stwierdzonych w uprawach oraz o zastosowaniu niedozwolonych preparatów zostały przekazane do Krajowego Punktu Kontaktowego w ramach systemu wczesnego ostrzegania o niebezpiecznej żywności i paszach (RASFF - Rapid Alert System for Food and Feed).

Najwięcej pozostałości ś.o.r. stwierdzono w uprawach kapusty pekińskiej i kapusty brukselskiej, natomiast najmniej w uprawie kalafiora. Najczęściej wykrywanymi substancjami były: chloropiryfos $\mathrm{z}$ grupy insektycydów fosforoorganicznych i azoksystrobina $z$ grupy fungicydów strobilurynowych. Wyniki te koreluja $\mathrm{z}$ wynikami otrzymanymi przez Łozowicką i wsp. (2012) w latach 2006-2009 na terenie Polski północno-wschodniej. W 2 przypadkach (2 próbki kapusty pekińskiej) wykryto pozostałości pirymetanilu - s.cz. wchodzącej w skład ś.o.r. niezalecanych do ochrony tej uprawy.

Tabela 1. Oznaczane substancje czynne w latach 2010-2012

Table 1. Analysed active substances in 2010-2012

\begin{tabular}{|c|c|}
\hline $\begin{array}{l}\text { Insektycydy } \\
\text { Insecticides }\end{array}$ & 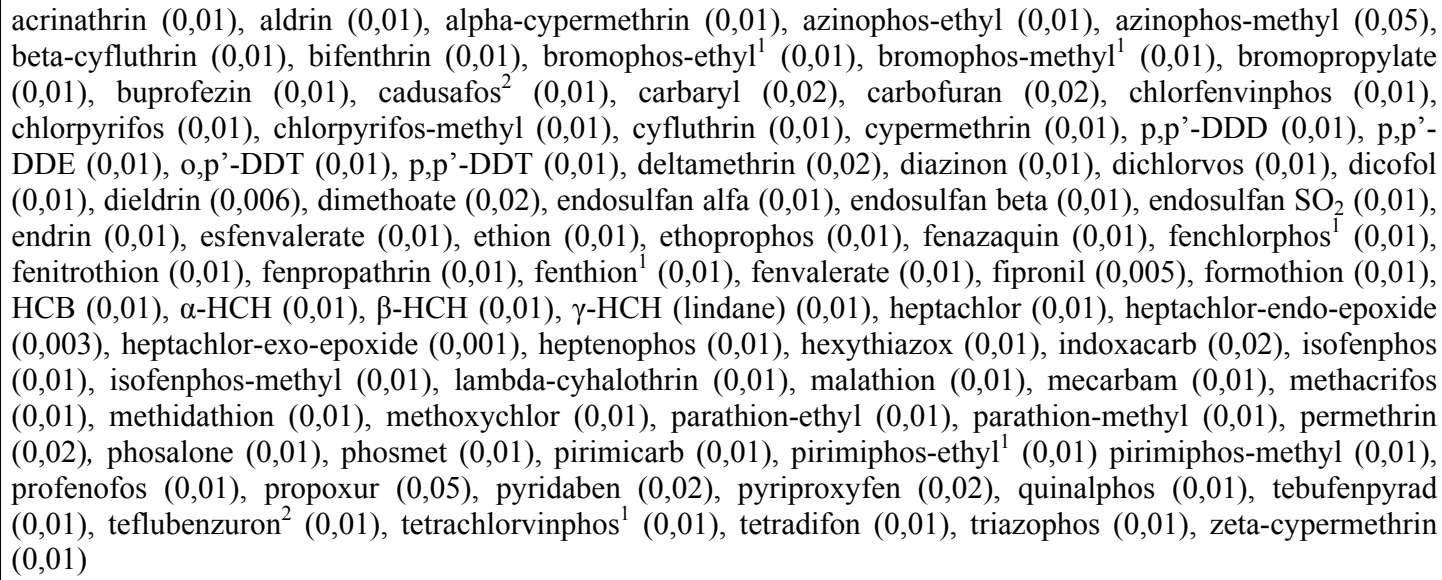 \\
\hline
\end{tabular}

azaconazole $^{1}(0,01)$, azoxystrobin $(0,01)$, benalaxyl $(0,05)$, bitertanol $(0,05)$, boscalid $(0,01)$, bromuconazole $(0,01)$, bupirimate $(0,01)$, chlorothalonil $(0,01)$, cyproconazole $(0,01)$, cyprodinil $(0,02)$, dichlofluanid $(0,01)$, dicloran $(0,01)$, difenoconazole $(0,01)$, dimethomorph $(0,01)$, dimoxystrobin ${ }^{1}(0,01)$, diniconazole ${ }^{1}(0,01)$, diphenylamine $(0,05)$, epoxiconazole $(0,01)$, fenarimol $(0,01)$, fenbuconazole $(0,02)$, fenhexamid $(0,05)$, Fungicydy $\quad$ fenpropimorph $(0,02)$, fludioxonil $(0,01)$, fluquinconazole $(0,01)$, flusilazole $(0,01)$, flutriafol ${ }^{1}(0,02)$, hexaconazole ${ }^{2}(0,01)$, imibenconazole ${ }^{1}(0,01)$, iprodione $(0,02)$, krezoxim-methyl $(0,01)$, mepanipyrim $(0,01)$, metalaxyl $(0,01)$, metconazole ${ }^{2}(0,02)$, myclobutanil $(0,01)$, penconazole $(0,01)$, pencycuron ${ }^{2}(0,05)$, picoxystrobin $(0,01)$, prochloraz $(0,01)$, procymidone $(0,01)$, propiconazole $(0,01)$, pyrazophos ${ }^{1}(0,01)$, pyrimethanil $(0,01)$, quinoxyfen $(0,01)$, quintozene $(0,01)$, tebuconazole $(0,02)$, tecnazene $(0,01)$, tetraconazole $(0,01)$, tolclofos-methyl $(0,01)$, tolylfluanid $(0,01)$, triadimefon $(0,01)$, triadimenol $(0,01)$, trifloxystrobin $(0,01)$, vinclozolin $(0,01)$, zoxamide ${ }^{2}(0,01)$

\begin{tabular}{|c|c|}
\hline $\begin{array}{l}\text { Herbicydy } \\
\text { Herbicides }\end{array}$ & $\begin{array}{l}\text { acetochlor }^{1}(0,01) \text {, atrazine }(0,01) \text {, bromacil }{ }^{2}(0,01) \text {, chlorpropham }(0,01) \text {, cyanazine }{ }^{2}(0,01) \text {, cyprazine }{ }^{2}(0,01) \text {, } \\
\text { diflufenican }^{2}(0,01) \text {, flurochloridone }{ }^{2}(0,01) \text {, lenacil }(0,05) \text {, metribuzin }(0,01) \text {, metazachlor }(0,01) \text {, napropamide } \\
(0,05) \text {, nitrofen }(0,01) \text {, oxyfluorfen }{ }^{2}(0,01) \text {, pendimethalin }(0,02) \text {, prometryn }(0,01) \text {, propachlor }(0,01) \text {, } \\
\text { propaquizafop }^{2}(0,05) \text {, propazine }{ }^{2}(0,01) \text {, propham }(0,02) \text {, propyzamide }(0,01) \text {, simazine }(0,01) \text {, trifluralin }(0,01)\end{array}$ \\
\hline $\begin{array}{l}\text { Regulatory wzrostu } \\
\text { Growth retardant }\end{array}$ & paclobutrazol $^{1}(0,01)$ \\
\hline
\end{tabular}

\footnotetext{
${ }^{1}$ substancje włączone do zakresu badań od 2011 roku - substances included in the scope of analysis from 2011

2 substancje włączone do zakresu badań od 2012 roku - substances included in the scope of analysis from 2012

W nawiasach podano granice oznaczalności w $\mathrm{mg} / \mathrm{kg}$ - In brackets the limits of determination were given in $\mathrm{mg} / \mathrm{kg}$
} 
Tabela 2. Występowanie pozostałości ś.o.r. w warzywach kapustnych, w latach 2010-2012

Table 2. Pesticide residues detected in brassica vegetables, in 2010-2012

\begin{tabular}{|c|c|c|c|c|c|c|c|}
\hline \multirow{2}{*}{$\begin{array}{l}\text { Uprawa } \\
\text { Crop }\end{array}$} & \multirow{2}{*}{$\begin{array}{c}\text { Liczba } \\
\text { badanych } \\
\text { próbek } \\
\text { Number of } \\
\text { analysed } \\
\text { samples }\end{array}$} & \multirow{2}{*}{$\begin{array}{l}\text { Substancja czynna } \\
\text { Active substance }\end{array}$} & \multicolumn{2}{|c|}{$\begin{array}{l}\text { Próbki z pozostałościami } \\
\text { Samples with residues }\end{array}$} & \multicolumn{2}{|c|}{$\begin{array}{c}\text { Zakres wykrywanych } \\
\text { pozostałości } \\
\text { Range of detected residues }\end{array}$} & \multirow{2}{*}{$\begin{array}{c}\text { NDP } \\
\text { MRL } \\
{[\mathrm{mg} / \mathrm{kg}]}\end{array}$} \\
\hline & & & $\begin{array}{l}\text { liczba } \\
\text { number }\end{array}$ & {$[\%]$} & $\underset{[\mathrm{mg} / \mathrm{kg}]}{\min }$ & $\underset{[\mathrm{mg} / \mathrm{kg}]}{\max }$ & \\
\hline \multirow{2}{*}{$\begin{array}{l}\text { Brokuł } \\
\text { Broccoli }\end{array}$} & \multirow{2}{*}{19} & chlorpyrifos & 3 & 16 & 0,02 & $0,08^{2}$ & 0,05 \\
\hline & & cypermethrin & 1 & 5 & 0,04 & - & 0,5 \\
\hline $\begin{array}{l}\text { Kalafior } \\
\text { Cauliflower }\end{array}$ & 34 & pirimicarb & 1 & 3 & 0,01 & - & 2 \\
\hline \multirow{3}{*}{$\begin{array}{l}\text { Kapusta głowiasta } \\
\text { Head cabbage }\end{array}$} & \multirow{3}{*}{19} & chlorpyrifos & 1 & 5 & 0,01 & - & 1 \\
\hline & & iprodione & 1 & 5 & 0,11 & - & 5 \\
\hline & & pirimicarb & 1 & 5 & 0,01 & - & 1 \\
\hline \multirow{3}{*}{$\begin{array}{l}\text { Kapusta brukselska } \\
\text { Brussels sprout }\end{array}$} & \multirow{3}{*}{5} & boscalid & 1 & 20 & 0,03 & - & 2 \\
\hline & & chlorpyrifos & 1 & 20 & 0,02 & - & 0,05 \\
\hline & & trifloxystrobin & 1 & 20 & 0,01 & - & 0,5 \\
\hline \multirow{11}{*}{$\begin{array}{l}\text { Kapusta pekińska } \\
\text { Chinese cabbage }\end{array}$} & \multirow{11}{*}{45} & azoxystrobin & 2 & 4 & 0,03 & - & 5 \\
\hline & & boscalid & 2 & 4 & 0,30 & 0,36 & 10 \\
\hline & & chlorpyrifos & 10 & 22 & 0,01 & $0,72^{2}$ & 0,5 \\
\hline & & chlorothalonil & 1 & 2 & $0,05^{2}$ & - & 0,01 \\
\hline & & lambda-cyhalothrin & 1 & 2 & 0,01 & - & 1 \\
\hline & & cypermethrin & 7 & 15 & 0,01 & 0,29 & 1 \\
\hline & & deltamethrin & 1 & 2 & 0,13 & - & 0,5 \\
\hline & & dimethoat & 3 & 7 & $0,03^{2}$ & $0,05^{2}$ & 0,02 \\
\hline & & iprodione & 3 & 7 & 0,06 & 1,28 & 5 \\
\hline & & pyrimethanil & 2 & 4 & $0,03^{1}$ & $0,04^{1}$ & 0,05 \\
\hline & & trifloxystrobin & 1 & 2 & $0,09^{2}$ & - & 0,02 \\
\hline
\end{tabular}

NDP - najwyższe dopuszczalne poziomy pozostałości - MRL - maximum residue limits

${ }^{1}$ substancja, której stosowanie nie jest zalecane w danej uprawie - application of the substance is not recommended for that crop

${ }^{2}$ substancja, której pozostałość przekroczyła najwyższy dopuszczalny poziom (NDP) - the substance which residue level exceeded the maximum residue limit (MRL)

Tabela 3. Oszacowanie długoterminowego (chronicznego) narażenia konsumentów na pozostałości ś.o.r. w warzywach kapustnych, w latach 2010-2012

Table 3. Estimation of long-term (chronic) dietary consumers' exposure to pesticide residues in brassica vegetables, in 2010-2012

\begin{tabular}{|c|c|c|c|c|c|c|c|c|c|}
\hline \multirow{3}{*}{$\begin{array}{c}\text { Uprawa } \\
\text { Crop }\end{array}$} & \multirow{3}{*}{$\begin{array}{c}\text { Substancja } \\
\text { czynna } \\
\text { Active substance }\end{array}$} & \multirow{3}{*}{\begin{tabular}{|c|} 
Średni poziom \\
pozostałości \\
Average \\
residue \\
level \\
[mg/kg] \\
$(\mathrm{RL})$
\end{tabular}} & \multirow{2}{*}{\multicolumn{2}{|c|}{$\begin{array}{c}97,5 \text { percentyl } \\
{[\mathrm{kg} / \text { dzień }]} \\
97.5 \text { percentile } \\
{[\mathrm{kg} / \text { day }]} \\
\text { (FR) }\end{array}$}} & \multirow{3}{*}{\begin{tabular}{|c|}
$\mathrm{ADI}$ \\
{$[\mathrm{mg} / \mathrm{kg}$} \\
$\mathrm{masy}$ ciała/ \\
$\mathrm{dzień}]$ \\
{$[\mathrm{mg} / \mathrm{kg}$} \\
body \\
weight/ \\
day $]$
\end{tabular}} & \multicolumn{4}{|c|}{ Pobranie - Intake } \\
\hline & & & & & & \multicolumn{2}{|c|}{$\begin{array}{l}\text { dorośli } \\
\text { adults } \\
(76 \mathrm{~kg})\end{array}$} & \multicolumn{2}{|c|}{$\begin{array}{l}\text { małe dzieci } \\
\text { toddlers } \\
(14,5 \mathrm{~kg})\end{array}$} \\
\hline & & & $\begin{array}{l}\text { dorośli } \\
\text { adults }\end{array}$ & $\begin{array}{l}\text { dzieci } \\
\text { toodlers }\end{array}$ & & $\begin{array}{c}\text { [mg/kg masy } \\
\text { ciała/dzień] } \\
{[\mathrm{mg} / \mathrm{kg} \text { body }} \\
\text { weight/day }]\end{array}$ & $\%$ ADI & $\begin{array}{c}{[\mathrm{mg} / \mathrm{kg} \text { masy }} \\
\text { ciała/dzień] } \\
{[\mathrm{mg} / \mathrm{kg} \text { body }} \\
\text { weight/day }]\end{array}$ & $\%$ ADI \\
\hline 1 & 2 & 3 & 4 & 5 & 6 & 7 & 8 & 9 & 10 \\
\hline \multirow{3}{*}{$\begin{array}{l}\text { Brokuł } \\
\text { Broccoli }\end{array}$} & chlorpyrifos & 0,04 & 0,0491 & 0,0248 & 0,01 & 0,0000258 & 0,26 & 0,0000684 & 0,68 \\
\hline & cypermethrin & 0,04 & 0,0491 & 0,0248 & 0,05 & 0,0000258 & 0,05 & 0,0000684 & 0,14 \\
\hline & \multicolumn{6}{|l|}{ łącznie - total } & 0,31 & & 0,82 \\
\hline \multirow{2}{*}{$\begin{array}{l}\text { Kalafior } \\
\text { Cauliflower }\end{array}$} & pirimicarb & 0,01 & 0,0662 & 0,0315 & 0,035 & 0,0000087 & 0,02 & 0,0000217 & 0,06 \\
\hline & \multicolumn{5}{|l|}{ łącznie - total } & & 0,02 & & 0,06 \\
\hline
\end{tabular}




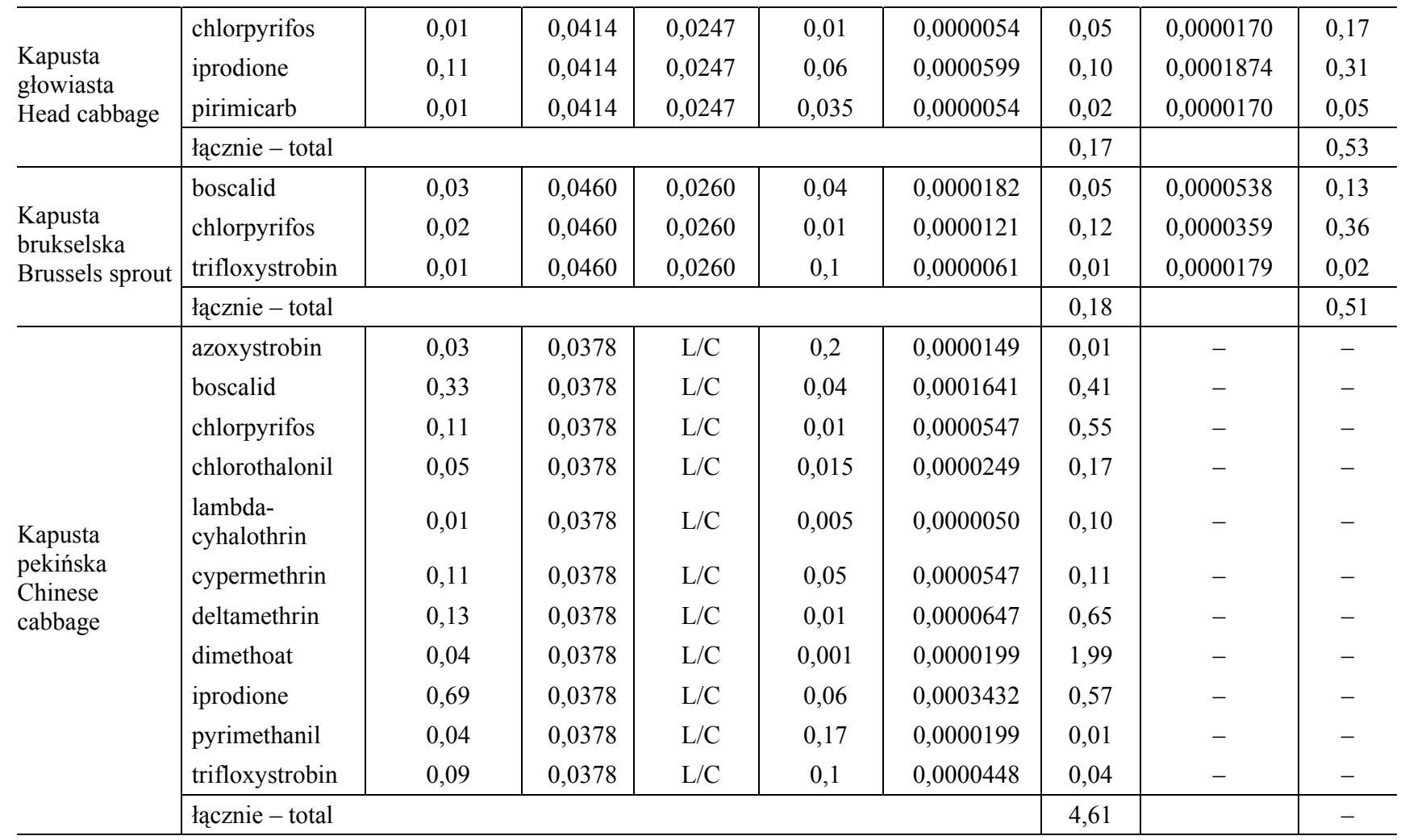

ADI - dopuszczalne dzienne pobranie - Acceptable Daily Intake

$\mathrm{L} / \mathrm{C}-$ niskie spożycie $(<0,1 \mathrm{~g} /$ dzień $)-$ low consumption $(<0.1 \mathrm{~g} /$ day $)$

Tabela 4. Oszacowanie krótkoterminowego (ostrego) narażenia konsumentów na pozostałości ś.o.r. w warzywach kapustnych, w latach 2010-2012

Table 4. Estimation of short-term (acute) dietary consumers' exposure to pesticide residues in brassica vegetables, in 2010-2012

\begin{tabular}{|c|c|c|c|c|c|c|c|c|c|c|}
\hline \multirow{3}{*}{$\begin{array}{l}\text { Uprawa } \\
\text { Crop }\end{array}$} & \multirow{3}{*}{$\begin{array}{l}\text { Substancja } \\
\text { czynna } \\
\text { Active } \\
\text { substance }\end{array}$} & \multirow{3}{*}{\begin{tabular}{|c|} 
Najwy- \\
ższy \\
poziom \\
pozosta- \\
łości \\
The higest \\
residue \\
level \\
{$[\mathrm{mg} / \mathrm{kg}]$} \\
$(\mathrm{HR})$
\end{tabular}} & \multirow{3}{*}{$\begin{array}{c}\text { Współ- } \\
\text { czynnik } \\
\text { zmienności } \\
\text { Varia- } \\
\text { bility factor } \\
\text { (v) }\end{array}$} & \multirow{2}{*}{\multicolumn{2}{|c|}{$\begin{array}{l}97,5 \text { percentyl } \\
\text { [kg/dzień] } \\
97.5 \text { percentile } \\
\text { [kg/day }] \\
\text { (LP) }\end{array}$}} & \multirow{3}{*}{$\begin{array}{c}\text { ARfD } \\
{[\mathrm{mg} / \mathrm{kg} \text { masy }} \\
\text { ciała/dzień }] \\
{[\mathrm{mg} / \mathrm{kg} \text { body }} \\
\text { weight/day }]\end{array}$} & \multicolumn{4}{|c|}{ Pobranie - Intake } \\
\hline & & & & & & & \multicolumn{2}{|c|}{$\begin{array}{l}\text { dorośli } \\
\text { adults } \\
\text { (76 kg) }\end{array}$} & \multicolumn{2}{|c|}{$\begin{array}{l}\text { małe dzieci } \\
\text { toddlers } \\
(14,5 \mathrm{~kg})\end{array}$} \\
\hline & & & & $\begin{array}{l}\text { dorośli } \\
\text { adults }\end{array}$ & $\begin{array}{l}\text { dzieci } \\
\text { toodlers }\end{array}$ & & $\begin{array}{c}{[\mathrm{mg} / \mathrm{kg} \text { masy }} \\
\text { ciała/dzień }] \\
{[\mathrm{mg} / \mathrm{kg} \text { body }} \\
\text { weight } / \text { day }]\end{array}$ & $\begin{array}{c}\% \\
\text { ARfD }\end{array}$ & $\left|\begin{array}{c}{[\mathrm{mg} / \mathrm{kg} \text { masy }} \\
\text { ciała/dzień }] \\
{[\mathrm{mg} / \mathrm{kg} \text { body }} \\
\text { weight } / \text { day }]\end{array}\right|$ & $\begin{array}{c}\% \\
\text { ARfD }\end{array}$ \\
\hline $\begin{array}{l}\text { Brokuł } \\
\text { Broccoli }\end{array}$ & chlorpyrifos & 0,08 & 5 & 0,1955 & 0,0607 & 0,1 & 0,001029 & 1,03 & 0,001674 & 1,67 \\
\hline \multirow{4}{*}{$\begin{array}{l}\text { Kapusta } \\
\text { pekińska } \\
\text { Chinese } \\
\text { cabbage }\end{array}$} & chlorpyrifos & 0,72 & \multirow{4}{*}{5} & 0,2348 & 0,0309 & 0,1 & 0,011122 & 11,12 & 0,007672 & 7,67 \\
\hline & chlorothalonil & 0,05 & & 0,2348 & 0,0309 & 0,6 & 0,000772 & 0,13 & 0,000533 & 0,09 \\
\hline & dimethoat & 0,05 & & 0,2348 & 0,0309 & 0,01 & 0,000772 & 7,72 & 0,000533 & 5,33 \\
\hline & trifloxystrobin & 0,09 & & 0,2348 & 0,0309 & $0,1^{*}$ & 0,001390 & 1,39 & 0,000959 & 0,96 \\
\hline
\end{tabular}

ARfD - ostra dawka referencyjna - Acute Reference Dose

*wartość dopuszczalnego dziennego pobrania (ADI) - value of Acceptable Daily Intake (ADI)

W badanych próbkach stwierdzono obecność pozostałości wielokrotnych. W 1 próbce kapusty pekińskiej wykryto obecność 4 związków, w 3 próbkach kapusty pekińskiej - 3 związków, w 6 próbkach (1 próbce brokułu,
1 próbce kapusty brukselskiej, 4 próbkach kapusty pekińskiej) 2 s.cz. ś.o.r. Szczegółowe dane o poziomach pozostałości ś.o.r. zamieszczone zostały w tabeli 2 . 
Badania wskazują na problemy rolników z ochroną kapusty pekińskiej, co związane jest m.in. $\mathrm{z}$ małą dostępnością zarejestrowanych preparatów do ochrony tej uprawy. Obecnie w zaleceniach zamieszczonych na stronie Ministerstwa Rolnictwa i Rozwoju Wsi znajduje się 14 fungicydów (2 s.cz. - fluazynam i azoksystrobina) i tylko 2 insektycydy (2 s.cz. - spirotetramat i tiachlopryd). Powszechnie używany Dursban 480 EC (s.cz. chlorpyrifos) - preparat przeciwko mszycy kapuścianej, gąsienicom: bielinka kapustnika, bielinka rzepnika, tantnisia krzyżowiaczka, piętnówki kapustnicy - nie jest już zalecany do ochrony kapusty pekińskiej.

Należy dodać, iż obecnie w Polsce, żaden herbicyd nie jest dopuszczony do stosowania w uprawach kapusty pekińskiej i brokułu. W przypadku ochrony kapusty brukselskiej zarejestrowanych jest 8 preparatów chwastobójczych, 1 insektycyd, brak natomiast zalecanych środków przeciwko chorobom grzybowym.

W tabeli 3. przedstawiono wyniki oszacowania długoterminowego narażenia konsumentów. Wyniki oszacowania narażenia krótkoterminowego dla produktów, w których stwierdzono przekroczenie NDP przedstawione zostały $\mathrm{w}$ tabeli 4 . Jak wynika $\mathrm{z}$ przeprowadzonych obliczeń narażenie długoterminowe i krótkoterminowe, zarówno dla dorosłych, jak i dzieci na pozostałości ś.o.r. zawartych $\mathrm{w}$ omawianej grupie warzyw jest niewielkie i nie przekracza dozwolonych wartości ADI i ARfD. Przedstawione w tabelach 3. i 4. dane wskazują, że spożywanie warzyw kapustnych jest „,bezpieczne” zarówno dla dorosłych, jak i dzieci, jednak z powodu stale zmieniających się programów ochrony roślin, badania powinny być kontynuowane i poszerzane zarówno pod względem liczby badanych substancji czynnych, jak i grup produktów.

\section{Wnioski / Conclusions}

1. Uzyskane wyniki badań wskazują na problemy rolników z ochroną kapusty pekińskiej przed szkodnikami i chorobami.

2. Oszacowane narażenie długoterminowe zdrowia konsumentów na pozostałości ś.o.r. pobierane $\mathrm{z}$ warzywami kapustnymi jest niewielkie, a więc nie ma niebezpieczeństwa wystąpienia zagrożenia dla zdrowia ludzi.

3. Oszacowane narażenie krótkoterminowe konsumentów na obecność pozostałości ś.o.r. występujących w uprawie brokułu i kapusty pekińskiej - produktów, w których wykryto poziomy pozostałości wyższe od dopuszczalnych wykazało, że nie ma obaw wystapienia niepożądanych skutków zdrowotnych dla ludzi.

4. Należy kontynuować badania na obecność pozostałości ś.o.r. dostosowując zakres badanych substancji czynnych do zmieniających się zaleceń ochrony.

\section{Literatura / References}

FAO/WHO. 2009. Principles and Methods for the Risk Assessment of Chemicals in Food. Dietary exposure assessment of chemicals in food. Food and Agriculture Organization, World Health Organization, Geneva, 95 pp.

Ludwicki J.K., Kostka G. 2008. Przekroczenia dopuszczalnych poziomów pozostałości pestycydów w żywności zgłaszane do oceny ryzyka zgodnie z procedurami RASFF w Polsce. Roczn. PZH 59: 389-396.

Łozowicka B., Jankowska M., Kaczyński P. 2012. Pesticide residues in Brassica vegetables and exposure assessment of consumers. Food Control 25: 561-575.

Pesticide Safety Directorate (PSD). 2006. New intake calculation models for consumer intake assessments. http://www. pesticides.gov.uk/guidance/industries/pesticides/topics/pesticide-approvals/pesticides-registration/data-requirements-handbook/ukconsumer-intake-models, accessed: 04.01.2013.

PN-EN ISO/IEC 17025. 2005. Ogólne wymagania dotyczące kompetencji laboratoriów badawczych i wzorcujących. PKN, Warszawa, 42 ss.

Rozporządzenie Ministra Zdrowia z dnia 17 października 2007 r. w sprawie pobierania próbek żywności w celu oznaczania poziomów pozostałości pestycydów (Dz. U. Nr 207, poz. 11501 i 1502: 14917-14929).

Rozporządzenie (WE) nr 396/2005 Parlamentu Europejskiego i Rady z dnia 23 lutego 2005 r. w sprawie najwyższych dopuszczalnych poziomów pozostałości pestycydów w żywności i paszy pochodzenia roślinnego i zwierzęcego oraz na ich powierzchni, zmieniające dyrektywę Rady 91/414/EWG (Dz. Urz. UE, L 70, z 16.03.2005 r., z późn. zm.).

Sadło S., Szpyrka E. 2001. Behaviour of pyrimethanil residues on tomato plants. J. Plant Prot. Res. 41 (3): 302-308.

Struciński P., Góralczyk K., Czaja K., Hernik A., Korcz W., Ludwicki J.K. 2007. Ocena ryzyka dla konsumenta przy przekroczeniach najwyższych dopuszczalnych poziomów pozostałości pestycydów (NDP) w żywności. Roczn. PZH 58: 377-388.

Ullmann's Agrochemicals: Plant and crop protection, Tom 2, 2007. Wiley-VCH-Verlag GmbH \& Co. KGaA, 912 pp.

Valverde-Garcia A., Gonzalez-Pradas E., Aguilera-des Real A. 1993. Analysis of buprofezin residues in vegetables. Application to the degradation study on eggplant grown in a greenhouse. J. Agric. Food Chem. 41 (12): 2319-2323.

WHO. 1997. Guidelines for predicting dietary intake of pesticide residues (revised). Global Environment Monitoring System - Food Contamination Monitoring and Assessment Programme (GEMS/Food) in collaboration with the Codex Committee on Pesticide Residues. Programme of Food Safety and Food Aid, World Health Organization, Geneva, 33 pp. 